\title{
AN UNUSUAL METHOD FOR DETERMINING THE PERCENTAGE OF HULLS IN OATS
}

\author{
Lauri Palohe imo \\ Department of Animal Husbandry, University of Helsinki.
}

Recived 15. 10. 1949.

The most convenient and also the most reliable means for establishing the feed value of oats is probably the determination of the percentage of hulls. In his textbook of animal husbandry the author (2) has introduced the following formula for calculating the feed value of air-dry oats: Feed Units per $\mathrm{kg}=1,050-0,008$. hull $-\%$. The formula is based on the assumption that $1 \mathrm{~kg}$ of hulled oat kernels is equal to 1,050 Scandinavian feed units and $1 \mathrm{~kg}$ of hulls equal to 0,25 units. In terms of the starchvalue system the formula would be as follows: 1bs. of Starch Value per 1 b. $=0,735-0,006 \cdot$ hull- $\%$.

During recent years we have used in this laboratory rats for hulling the oats since it was observed that rats eat only the kernels neglecting the hulls. The procedure is executed in the following manner:

The animals to be used as aids are kept without food for one night. Two $20 \mathrm{~g}$ portions of oats previously cleansed of foreign materials are weighed; the one serves for the determination of moisture, the other for hulling. 2-3 rats are placed upon a sheet of blotting paper on a table and covered with a cage. The oats are spread in the cage in 3-4 successive portions. Being hungry the animals immediately begin to eat. In the customary half-sitting posture they hull one grain after another without swallowing any chip of the hulls but lear ing the point (apex) of every kernel uneaten. These fragments are nevertheless remowed from the hulls. The firts portion having been eaten the blotting-paper is changed and another portion given. The residues are shaken down on a sheet of writing-paper, cleared from the kernel particles and put into a weighing-box. After drying at $100-105^{\circ} \mathrm{C}$ the dry weight of the hulls is obtained. Finally, the percentage of dry hulls in the dried unhulled kernels is calculated.

The rats pick up the grain by their front teeth (incisors), hold it tranversely before the mouth with their paws and tear out the inner hull-leaf (palet) by their 
The table shows the accuracy of the work of rats in hulling the oats.

\begin{tabular}{|c|c|c|c|c|}
\hline \multirow{2}{*}{$\frac{\text { No of sample }}{1}$} & \multicolumn{2}{|r|}{ Variety of oats } & \multicolumn{2}{|c|}{ Percentage of hulls when hulled } \\
\hline & Guldregn & n II $\quad \ldots \ldots \ldots \ldots \ldots$ & 24,64 & 24,69 \\
\hline 2 & $"$ & $\ldots \ldots \ldots \ldots$ & 25,35 & 25,27 \\
\hline 3 & $"$ & $\ldots \ldots \ldots \ldots \ldots$ & 24,82 & 24,69 \\
\hline 4 & Kytö . . & $\ldots \ldots \ldots \ldots \ldots \ldots$ & 24.65 & 24.72 \\
\hline 5 & $"$ & $\ldots \ldots \ldots \ldots \ldots \ldots$ & 25.05 & 24.40 \\
\hline 6 & $"$ & $\ldots \ldots \ldots \ldots \ldots \ldots$ & 24.49 & 24.69 \\
\hline 7 & Russian is & import...$\ldots \ldots \ldots$ & 27.96 & 27.98 \\
\hline 8 & $"$ & $" \quad \ldots \ldots \ldots \ldots$ & 28.61 & 28.29 \\
\hline 9 & $"$ & $" \quad \ldots \ldots \ldots \ldots$ & 28.24 & 28.19 \\
\hline 10 & Orion II & $\ldots \ldots \ldots \ldots \ldots \ldots$ & 25,37 & 25,6 I \\
\hline 11 & $"$ & $\ldots \ldots \ldots \ldots \ldots$ & 25,53 & 25,52 \\
\hline 12 & $"$ & $\ldots \ldots \ldots \ldots \ldots$ & 25,38 & 25,30 \\
\hline 13 & Tammi & $\ldots \ldots \ldots \ldots \ldots \ldots$ & 21,78 & 22,60 \\
\hline 14 & " & $\ldots \ldots \ldots \ldots \ldots \ldots$ & 22,16 & 22,18 \\
\hline 15 & $"$ & $\ldots \ldots \ldots \ldots \ldots \ldots$ & 22,19 & 22,63 \\
\hline 16 & Sisu $\ldots$. & $\ldots \ldots \ldots \ldots \ldots \ldots$ & 20,82 & 21,21 \\
\hline 17 & $" \ldots$. & $\ldots \ldots \ldots \ldots \ldots \ldots$ & 20,76 & 20,98 \\
\hline 18 & $" \ldots$. & $\ldots \ldots \ldots \ldots \ldots \ldots \ldots$ & 21,16 & 21,00 \\
\hline 19 & Eho .... & $\ldots \ldots \ldots \ldots \ldots \ldots$ & 21,59 & 21,87 \\
\hline 20 & $" \ldots$ & $\ldots \ldots \ldots \ldots \ldots \ldots$ & 21,66 & 21,72 \\
\hline 21 & $" \ldots$ & $\ldots \ldots \ldots \ldots \ldots \ldots$ & 21,56 & 21,83 \\
\hline
\end{tabular}

incisors. The kernel comes forth the base (the germ-part) first and the rat begins eating this part. The point fraction of the kernel, remaining in the paws of the rat to the very last, is difficult to place in the mouth and is therefore discarded.

For examining the accuracy of the work of our small laboratory aids the percentage of hulls was determined in a series of oat samples, parallel by rats and by hand. The results presented in enclosed table convincingly show that one may trust in the work of the rats.

This investigation contributes also to our knowledge of the food-habits of the rat. The fact that the rats so carefully avoid eating the chips of the oat hulls is presumably a very typical feature in their eating habits and characterizes their inclination to concentrated foods. CARLSON and HoELzel (1) report that rats often eat only the germ part of the kernels of corn, and that the gnawing out of the germ part of corn by rats seems to be so precise that it has been regarded as a reliable method of determining the proportion of germ in the kernels of corn. In our experiments with oat grains no such preference was observed. The reason of discarding the point-fraction of the kernels seems to be merely of technical nature.

The animals used in the experiments were of a local inbred strain of yellowhood rats. 


\section{REFERENCES.}

(1) Carlson, Anton J. and Hoelzel, Frederick 1949, Influence of Texture of Food on its Acceptance by Rats. Science, 109, p. 63.

(2) Paloheimo, Lauri 1947. Kotieläinhoidon perusteita. Jyväskylä.

SELOST US.

OMALAATUINEN MENETELMÄ KAURAN KUORIPROSENTIN MÄÄRITTÄMISEKSI.

LAURI PALOHEIMO

Helsingin Yliopisto, Kotieläintieteellinen laitos.

Menetelmä perustuu siihen havaintoon, että rotat, saadessaan ruoakseen kauran jyviä, kuorivat huolellisesti jyvät, eivätkä niele ollenkaan kuoren siruja. Kirjoitukseen liittyvässä taulukossa nähdään vierekkäin asetettuina kuoriprosentit, jotka on saatu a) rottien toimiessa kuorijoina ja b) käsin kuorimalla. 